\title{
Chemical Speciation, Bioavailability and Risk Assessment of Potentially Toxic Metals in Highway Dusts as Indicators of Highway Pollution
}

\author{
Festus Mayowa Adebiyi ${ }^{1}$, Abiodun Odunlami Adegunwa ${ }^{2}$, Odunayo Timothy Ore ${ }^{1, *}$, \\ Godswill Ehimengbale Akhigbe ${ }^{3}$ \\ ${ }^{1}$ Department of Chemistry, Obafemi Awolowo University, Ile-Ife, Nigeria \\ ${ }^{2}$ Department of Pure and Applied Chemistry, Osun State University, Osogbo, Nigeria \\ ${ }^{3}$ Department of Chemistry, McPherson University, Ajebo, Nigeria
}

Email address:

oreodunayo@yahoo.com (O. T. Ore)

${ }^{*}$ Corresponding author

\section{To cite this article:}

Festus Mayowa Adebiyi, Abiodun Odunlami Adegunwa, Odunayo Timothy Ore, Godswill Ehimengbale Akhigbe. Chemical Speciation, Bioavailability and Risk Assessment of Potentially Toxic Metals in Highway Dusts as Indicators of Highway Pollution. Modern Chemistry. Vol. 7, No. 2, 2019, pp. 30-37. doi: 10.11648/j.mc.20190702.12

Received: August 11, 2019; Accepted: August 29, 2019; Published: September 17, 2019

\begin{abstract}
This paper investigated concentrations of heavy metals in roadside soil dusts collected along Ife-Ibadan highway in Osun state, Nigeria with the aim of assessing the impacts of vehicular emissions on the environments. The soil dusts were analyzed for total metal concentrations and speciation using Atomic absorption spectrophotometry followed by the evaluation of the metal bioavailability. Results of the total metal analysis indicated that the concentrations of the metals $(\mathrm{Pb}, \mathrm{Zn}, \mathrm{Cu}, \mathrm{Fe}$ and $\mathrm{Mn}$ ) were higher in the contaminated soils than control soils and their WHO maximum allowable limits. The pattern of the total mean concentrations of the metals is in the order: $\mathrm{Fe}>\mathrm{Cu}>\mathrm{Mn}>\mathrm{Zn}>\mathrm{Pb}$. The contamination factors of the metals showed that the soils suffered contamination. Analysis of variance (ANOVA) revealed that differences existed significantly in the mean values for all the metals across the study sites. Strong correlation among the metals signified common contamination sources. Cluster analysis produced two major groups: $\mathrm{A}(\mathrm{Fe}$ and $\mathrm{Cu}$ ) and $\mathrm{B}(\mathrm{Zn}, \mathrm{Mn}$ and $\mathrm{Pb}$ ) which is subdivided into two subgroups viz: $\mathrm{Bi}(\mathrm{Zn}$ and $\mathrm{Mn})$ and $\mathrm{Bii}(\mathrm{Pb})$, indicating similar chemical properties/or sources. The results of the $\mathrm{T}$-test indicated that there were significant differences between the concentrations of the metals in contaminated and control soils. The chemical pools of the metals indicated that the metals were distributed into six fractions with most of the metals residing in the non-residual fractions, suggesting how readily the metals are released into the environment.
\end{abstract}

Keywords: AAS, Chemical Speciation, Contamination, Toxic Metals, Highway, Soil Dust

\section{Introduction}

Roads are known as the second largest non-point source of creating pollution in urban environment [1]. Dust particles that accumulate along highway usually comprise of both atmospheric and vehicular emissions and are governed by meteorological factors.

However, human activities such as smelting, vehicular emissions, urban construction, industrial combustion, manufacture and use of pesticides also influence their chemical composition. Once soil dusts are generated and released to the atmosphere, they travel long distances from emission point source by turbulent atmospheric currents and finally settles by gravity under and brought to the surface by precipitation [2].

Road side dust is one of the sources of heavy metals that may originate from either anthropogenic such as high vehicle traffic volumes, building materials, fuel burnings, corrosion of different parts of vehicle (e.g. tires, batteries, and alloys) or natural sources such as local soil. In the course of transportation, the suspended metals are loaded to particulates; hence the dust creates a reserve pool of metals in urban atmosphere. Hence, road dust could be considered as a carrier of potentially hazardous compounds that can easily be 
re-suspended through recirculation in the air form the earth's surface and vice-versa. The most common heavy metals released from vehicles on road are cadmium $(\mathrm{Cd})$, copper $(\mathrm{Cu})$, lead $(\mathrm{Pb})$, nickel $(\mathrm{Ni})$, iron (Fe), and zinc ( $\mathrm{Zn})$ [3]. Most trace metals such as $\mathrm{Pb}, \mathrm{As}, \mathrm{Hg}$ and $\mathrm{Cd}$ are toxic even at extremely low concentrations and are initiators of many diseases in human [4]. Concentrations of heavy metals in the environment result in health hazards such as adversely affecting the nervous, blood forming, cardiovascular, renal and reproductive systems. Others include reduced intelligence, attention deficit and behavioral abnormality [5].

The common approach used in assessing the negative impacts of these heavy metals in dust samples has been the measurement of its total concentration owing to an assumption that all forms of the species are equally toxic to humans. This approach provides no information about the fate of metals in terms of its bioavailability. Therefore, to fully assess the potential toxicity of metals in the environment, data on the speciation analysis of metals must be considered along with those of the total metal concentration [6].

Studies on the distribution and speciation of heavy metals in dust can provide not only information on the degree of pollution, but especially the actual environmental impact on metal bioavailability as well as their origin.

The heavy metals chosen for this study were $\mathrm{Pb}, \mathrm{Cu}, \mathrm{Zn}$, $\mathrm{Mn}$ and $\mathrm{Fe}$ because of their extreme toxicity to human even at very low concentrations. The aim of the present work was to study the total concentration and speciation of selected heavy metals of soil dust along Ife- Ibadan express roads and terminuses with the view of understanding the levels of potentially harmful species.

\section{Materials and Methods}

\subsection{Sample Collection and Preparation}

Soil dust samples were collected using hand trowel from different equidistance points of $100 \mathrm{~m}$ along the IfeIbadan express way in five locations, while control soil dust samples were collected from areas where there were little or no anthropogenic influences. The coordinates of the sample locations are presented in Table 1. The collected samples were stored in air and moisture proof plastic containers and were taken to the laboratory immediately for analysis. The samples were air-dried and sieved through a $2 \mathrm{~mm}$ sieve and kept in closed container at room temperature.

Table 1. A Table showing the Sampling Sites and their Coordinates.

\begin{tabular}{|c|c|c|}
\hline $\mathbf{S} / \mathbf{N}$ & Site & Coordinate \\
\hline 1. & A & $7^{\circ} 29^{\prime} 33^{\prime \prime} \mathrm{N} 4^{\circ} 33^{\prime} 15^{\prime \prime} \mathrm{E}$ \\
\hline 2. & $\mathrm{~B}$ & 7²9'15’'N 4³9'09'” \\
\hline 3. & $\mathrm{C}$ & $7^{\circ} 29^{\prime} 26^{\prime \prime} \mathrm{N} 4^{\circ} 36^{\prime} 24^{\prime \prime} \mathrm{E}$ \\
\hline 4. & $\mathrm{D}$ & $7^{\circ} 29^{\prime} 25^{\prime \prime} \mathrm{N} 4^{\circ} 36^{\prime} 24^{\prime \prime} \mathrm{E}$ \\
\hline 5. & $\mathrm{E}$ & $7^{\circ} 29^{\prime} 25^{\prime \prime} \mathrm{N} 4^{\circ} 36^{\prime} 26^{\prime \prime} \mathrm{E}$ \\
\hline 6. & CTR 1 & $7^{\circ} 29^{\prime} 39^{\prime \prime} \mathrm{N} 4^{\circ} 30^{\prime} 50^{\prime \prime} \mathrm{E}$ \\
\hline 7. & CTR 2 & $7^{\circ} 31^{\prime} 42^{\prime \prime} \mathrm{N} 4^{\circ} 30^{\prime} 44^{\prime \prime} \mathrm{E}$ \\
\hline 8. & CTR 3 & 7²9'27'N 4³1'06”'E \\
\hline
\end{tabular}

\subsection{Analysis of Metal Total Concentration}

Heavy metals in the dust samples were digested using the USEPA method 3050B following [7]. Dust sample (1g) was suspended in $15 \mathrm{ml}$ of $1: 11$ nitric acid: water solution and heated at $105^{\circ} \mathrm{C}$ for $6 \mathrm{~h}$. After cooling, $1 \mathrm{ml}$ of $30 \% \mathrm{H}_{2} \mathrm{O}_{2}$ was added and digested for additional $30 \mathrm{~min}$ before bringing the samples to a $50 \mathrm{ml}$ volume with deionized water. Metal concentrations were analyzed using flame atomic absorption spectrometer (FAAS) PG990. Blank determinations were also carried out to serve as quality control analysis.

\subsection{Sequential Extraction of Heavy Metal}

Metals were fractionated using liquid extraction according to the procedure of [8] which is a modified version of [9]. The metal species were extracted into six fractions according to the following methods:

\section{Water soluble fraction (F1)}

Exactly $1.0 \mathrm{~g}$ of air-dried soil sample each was mixed with $10 \mathrm{~mL}$ distilled water with continuous agitation using mechanical shaker for 1 hour. This was then centrifuged and the supernatants decanted and made up to $25 \mathrm{~mL}$ with distilled water and stored in a cleaned plastic container.

Exchangeable fraction ( $F 2$ )

The residue from $\mathrm{F} 1$ was extracted at room temperature for 1 hour with $20 \mathrm{~mL} 1 \mathrm{M} \mathrm{MgCl}_{2}$ solution at $\mathrm{pH} 7$. The mixture was thoroughly agitated throughout the extraction.

Bound to carbonates (F3)

The residue of F2 was extracted with $20 \mathrm{~mL}$ of $1 \mathrm{M}$ sodium acetate/acetic acid buffer at $\mathrm{pH} 5$ for 5 hours at room temperature. The extracted metal solution was decanted from the residual soil samples. The residual sediment was used for the next extraction.

Bound to iron and manganese oxides (F4)

The residue from F3 was extracted under mild reducing conditions as follows: Hydroxyl amine hydrochloride $\left(\mathrm{NH}_{2} \mathrm{OH} . \mathrm{HCl}\right)$ weighing $0.69 \mathrm{~g}$ was dissolved in $250 \mathrm{~mL}$ distilled water to prepare $0.04 \mathrm{M} \mathrm{NH} \mathrm{N}_{2} \mathrm{OH} . \mathrm{HCl}$. The residue was extracted with $20 \mathrm{~mL}$ of $0.04 \mathrm{M} \mathrm{NH} \mathrm{NH}_{2} \mathrm{OH} . \mathrm{HCl}$ in $25 \%$ (v/v) acetic acid with agitation at $96^{\circ} \mathrm{C} \pm 1^{\circ} \mathrm{C}$ in a water bath for 6 hours. The extract was decanted from the residual sediment which was used for the next extraction.

Bound to organic matter and sulphide (F5)

The residue from $\mathrm{F} 4$ was oxidized as follows: $3 \mathrm{~mL}$ of $0.02 \mathrm{M} \mathrm{HNO}_{3}$ and $5 \mathrm{~mL}$ of $30 \%(\mathrm{v} / \mathrm{v})$ hydrogen peroxide, which has been adjusted to $\mathrm{pH} 2$, was added to the residue from F4. The mixture was heated to $85^{\circ} \mathrm{C}$ in a water bath for 2 hours with occasional agitation and allowed to cool down. Another $3 \mathrm{~mL}$ of $30 \%$ hydrogen peroxide, adjusted to $\mathrm{pH} 2$ with $\mathrm{HNO}_{3}$, was then added. The mixture was heated again at $85^{\circ} \mathrm{C}$ for 3 hours with occasional agitation and allowed to cool down. Then $5 \mathrm{~mL}$ of $3.2 \mathrm{M}$ ammonium acetate in $20 \%$ (v/v) $\mathrm{HNO}_{3}$ was added, followed by dilution to a final volume of $20 \mathrm{~mL}$ with de-ionized water. The extracted metal solution was decanted from the residual sediment which was used for the next extraction. 


\section{Residual or inert fraction (F6)}

Residue from F5 was oven dried at $105^{\circ} \mathrm{C}$. Digestion was carried out with a mixture of $5 \mathrm{~mL}$ conc. $\mathrm{HNO}_{3}\left(\mathrm{HNO}_{3}, 70 \%\right.$ $\mathrm{w} / \mathrm{w}), 10 \mathrm{~mL}$ hydrofluoric acid (HF, $40 \% \mathrm{w} / \mathrm{w})$ and $10 \mathrm{~mL}$ perchloric acid $\left(\mathrm{HClO}_{4}, 60 \% \mathrm{w} / \mathrm{w}\right)$ in Teflon beakers. The fractions (extracts) were then taken for AAS determination.

\subsection{Assessment of Metal Contamination}

For the interpretation of the geochemical data the following statistical methods were used: Descriptive statistics (mean, range, standard deviation) were performed in addition to contamination factor, enrichment factor, pollution load index, modified degree of contamination and potential ecological risk assessments to investigate the pollution status of the soil dusts. Cluster analysis and T-test were also used to interpret the results. Mobility factor was determined to have an understanding of the level of availability of the metals in the environment studied [10-14].

\section{Results and Discussion}

\subsection{Elemental Analysis}

The results of the recovery analysis are presented in Table 2 .

Table 2. Analytical Results for Calibration Curve and Percentage Recovery $(\%$ R) for Heavy Metals.

\begin{tabular}{llll}
\hline $\begin{array}{l}\text { Heavy } \\
\text { metals }\end{array}$ & $\begin{array}{l}\text { Amount spiked } \\
(\boldsymbol{\mu g} / \mathbf{g})\end{array}$ & $\begin{array}{l}\text { Amount } \\
\text { recovered }(\boldsymbol{\mu g} / \mathbf{g})\end{array}$ & \% Recovery \\
\hline $\mathrm{Pb}$ & 5.00 & 4.65 & 93.00 \\
$\mathrm{Cu}$ & 5.00 & 4.26 & 85.20 \\
$\mathrm{Zn}$ & 5.00 & 4.35 & 87.00 \\
$\mathrm{Fe}$ & 5.00 & 4.15 & 83.00 \\
\hline
\end{tabular}

The range and mean concentrations of the analyzed metals (Fe, $\mathrm{Zn}, \mathrm{Mn}, \mathrm{Pb}$, and $\mathrm{Cu}$ ) in the soil dust and control samples are shown in tables 3 and 4 respectively.

Table 3. Heavy metal concentration $(\mu \mathrm{g} / \mathrm{g})$ in the dust samples from study area.

\begin{tabular}{lllllll}
\hline Samples & Fe & Zn & Mn & Pb & Cu \\
\hline A & $33.50 \pm 0.75$ & $9.00 \pm 0.10$ & $16.00 \pm 0.40$ & $6.90 \pm 0.15$ & $28.00 \pm 0.65$ \\
B & $29.50 \pm 0.60$ & $11.00 \pm 0.20$ & $12.50 \pm 0.45$ & $6.10 \pm 0.12$ & $27.00 \pm 0.70$ \\
C & $27.00 \pm 0.55$ & $8.50 \pm 0.10$ & $10.50 \pm 0.40$ & $7.00 \pm 0.11$ & $23.00 \pm 0.85$ \\
D & $28.00 \pm 0.70$ & $11.50 \pm 0.15$ & $14.50 \pm 0.50$ & $5.90 \pm 0.14$ & $28.00 \pm 0.55$ \\
E & $26.50 \pm 0.55$ & $10.00 \pm 0.05$ & $15.00 \pm 0.40$ & $6.90 \pm 0.11$ & $27.50 \pm 0.65$ \\
Mean \pm SD & $28.90 \pm 0.63$ & $10.00 \pm 0.12$ & $13.70 \pm 0.43$ & $6.56 \pm 0.13$ & $26.70 \pm 0.68$ \\
Range & $26.50-33.50$ & $8.50-11.50$ & $10.50-16.00$ & $5.90-6.90$ & 2.05 \\
CV (\%) & 2.18 & 1.20 & 3.14 & 1.98 & $85.00 \pm 2.07$ & 28.00 \\
WHO Limit & 0.3 & 3.0 & 0.1 & 0.01 & $76.00 \pm 2.04$ & 2.55 \\
\hline
\end{tabular}

Table 4. Heavy metal concentration $(\mu \mathrm{g} / \mathrm{g})$ in the control samples.

\begin{tabular}{lllllll}
\hline Sample & Fe & Zn & Mn & Pb & Metal Burden \\
\hline Control 1 & $33.00 \pm 0.85$ & $8.50 \pm 0.05$ & $10.00 \pm 0.45$ & $5.80 \pm 0.11$ & $25.50 \pm 0.45$ \\
Control 2 & $23.00 \pm 0.45$ & $9.50 \pm 0.05$ & $16.00 \pm 0.30$ & $5.60 \pm 0.14$ & $21.50 \pm 0.85$ \\
Control 3 & $19.50 \pm 0.40$ & $6.50 \pm 0.15$ & $10.00 \pm 0.80$ & $5.60 \pm 0.14$ & $23.00 \pm 0.85$ \\
Mean \pm SD & $25.17 \pm 0.57$ & $8.17 \pm 0.08$ & $12.00 \pm 0.52$ & $5.67 \pm 0.13$ & $23.33 \pm 0.72$ \\
Range & $19.50-33.00$ & $6.50-8.50$ & $10.00-16.00$ & $5.60-5.80$ & $64.60 \pm 2.34$ \\
CV $(\%)$ & 2.26 & 1.00 & 4.33 & 2.29 & $74.33 \pm 2.02$ & $3.09-25.50$ \\
\hline
\end{tabular}

It is observed that the concentrations of the analyzed metals in the samples were relatively high and varied as follows: $\mathrm{Fe}$ $(26.50-33.50 \mu \mathrm{g} / \mathrm{g}) ; \quad \mathrm{Zn} \quad(8.50-11.50 \mu \mathrm{g} / \mathrm{g}) ; \mathrm{Mn} \quad(10.50$ $16.00 \mu \mathrm{g} / \mathrm{g}) ; \mathrm{Pb}(5.90-6.90 \mu \mathrm{g} / \mathrm{g})$ and $\mathrm{Cu}(23.00-28.00 \mu \mathrm{g} / \mathrm{g})$. Iron has the highest mean value of $26.50 \mu \mathrm{g} / \mathrm{g}$ and $\mathrm{Pb}$ has the least mean value of $6.90 \mu \mathrm{g} / \mathrm{g}$. The mean concentration of $\mathrm{Zn}$ $(10.00 \mu \mathrm{g} / \mathrm{g})$ was found lower than that reported by [15] but was higher than the WHO tolerable limit of $0.3 \mu \mathrm{g} / \mathrm{g}$. The presence of $\mathrm{Zn}$ in the dust might be due extensive use of $\mathrm{Zn}$ compounds as anti-oxidants and detergent/depressants to improve motor oil agent. Also, vehicle brake linings and tire wear have been identified as possible sources of $\mathrm{Zn}$. The mean concentration of $\mathrm{Pb}(6.56 \mu \mathrm{g} / \mathrm{g})$ recorded for $\mathrm{Pb}$ was found to be consistent with the values reported in Osogbo by [1]. In line with literature report that surface soil contains higher concentration of $\mathrm{Cu}$ [16]. The observed mean concentration of $\mathrm{Cu}(26.70 \mu \mathrm{g} / \mathrm{g})$ in this study was also found to be higher than its maximum tolerable limit [17]. However, highest values were obtained in the higher traffic sites, A $(28.00 \mu \mathrm{g} / \mathrm{g})$ and $\mathrm{E}$
$(27.50 \mu \mathrm{g} / \mathrm{g})$. Toxicity of $\mathrm{Cu}$ for humans is usually not common [18] but due to its bioaccumulation, continuous exposure to $\mathrm{Cu}$ can be detrimental to human. Manganese recorded mean concentration of $13.70 \mu \mathrm{g} / \mathrm{g}$ with the highest value obtained at site $\mathrm{A}(16.00 \mu \mathrm{g} / \mathrm{g})$ and the lowest concentration at site $\mathrm{C}$ $(14.50 \mu \mathrm{g} / \mathrm{g})$. The sources of $\mathrm{Mn}$ in roadside dust are believed to be due to corrosion of vehicular parts [19]. The rate of high corrosion and wear from old vehicles (as a result of high patronage in imported used cars) plying the roads could have accounted for the significant levels of anthropogenic contributions of $\mathrm{Mn}$ to roadside dusts.

The results also reveal that $\mathrm{Fe}(26.50 \mu \mathrm{g} / \mathrm{g})$ has the highest mean concentration while $\mathrm{Pb}(6.90 \mu \mathrm{g} / \mathrm{g})$ has the least mean concentration. The order of decreasing mean values is $\mathrm{Fe}>$ $\mathrm{Cu}>\mathrm{Mn}>\mathrm{Zn}>\mathrm{Pb}$. The most contaminated sample from the total metal burden was sample site $A$ with a value of (93.00 \pm 2.05$)$, while sample site $C$ was the least contaminated with heavy metals with a value of $(76.00 \pm 2.01)$. The high concentration of the investigated heavy metals in site A can 
be due to traffic speed and volume which are the two important factors that influences metal concentrations in the urban atmosphere [20]. Additionally, driving conditions (stop and go or free cruising conditions, brake or acceleration maneuvers) can as well influence the differences of metal concentrations among these sites [20]. It is also observed that the mean concentrations of the analyzed metals are higher in the dust samples than that of the control samples.

The values obtained for the enrichment factor for the analyzed metals are presented in Table 5.

Table 5. Contamination Factor (CF), Enrichment Factor (EF), modified degree of contamination $(m C d)$ and pollution load index (PLI) of the analyzed heavy metals.

\begin{tabular}{lllll}
\hline Metal & CF & EF & Tr & Er \\
\hline $\mathrm{Fe}$ & 1.15 & & & \\
$\mathrm{Zn}$ & 1.22 & 0.21 & 1 & 1.22 \\
$\mathrm{Mn}$ & 1.14 & 0.19 & 1 & 1.14 \\
$\mathrm{~Pb}$ & 1.16 & 0.20 & 5 & 5.80 \\
$\mathrm{Cu}$ & 1.14 & 0.19 & 5 & 5.70 \\
$\mathrm{mCd}$ & 1.16 & & & \\
$\mathrm{PLI}$ & 1.16 & & & 13.86 \\
$\mathrm{RI}$ & & & & \\
\hline
\end{tabular}

$\mathrm{T}_{\mathrm{r}}=$ Toxicological response factor, $\mathrm{E}_{\mathrm{r}}=$ Potential ecological risk factor, $\mathrm{RI}=$ Potential ecological risk index.

These results suggest that all metals showed no enrichment
$($ EF $<1)$, suggesting possible mobilization of metals as a result of runoffs. The result was contrary to those previously reported by the study [21] that reported moderate $(\mathrm{Cu}, \mathrm{Zn}$ and $\mathrm{Fe}$ ) to extreme $(\mathrm{Pb})$ enrichment in most roadside soils studied. The contamination factors of the analyzed metals in the roadside soil dusts show that the soils suffer moderate contamination by the heavy metals.

Statistical evaluation using one-way analysis of variance (ANOVA) was carried out to correlate the significant differences for the investigated metals between the different chosen locations. The output of the analysis reveal that differences exist significantly in the mean value for all the metals across the study sites. The p-values for the metals were seen to be about (0.09) much less than the level of significance (2.86). This indicates there is significant difference in the mean values of the metals such as $\mathrm{Pb}, \mathrm{Fe}$, $\mathrm{Zn}, \mathrm{Cu}$ and $\mathrm{Mn}$ across the study areas. The strong correlation signifies that all the paired metals are dependent on common contamination sources. The cluster analysis of the analyzed metals (Figure 1) grouped the heavy metals into clusters on the basis of similarities within a group and dissimilarities between different groups. Cluster analysis produced two major groups: $\mathrm{A}(\mathrm{Fe}$ and $\mathrm{Cu})$ and $\mathrm{B}(\mathrm{Zn}, \mathrm{Mn}$ and $\mathrm{Pb})$ which is subdivided into two sub-groups viz: $\mathrm{Bi}(\mathrm{Zn}$ and $\mathrm{Mn})$ and $\mathrm{Bii}$ $(\mathrm{Pb})$, indicating similar chemical properties/or sources [22].

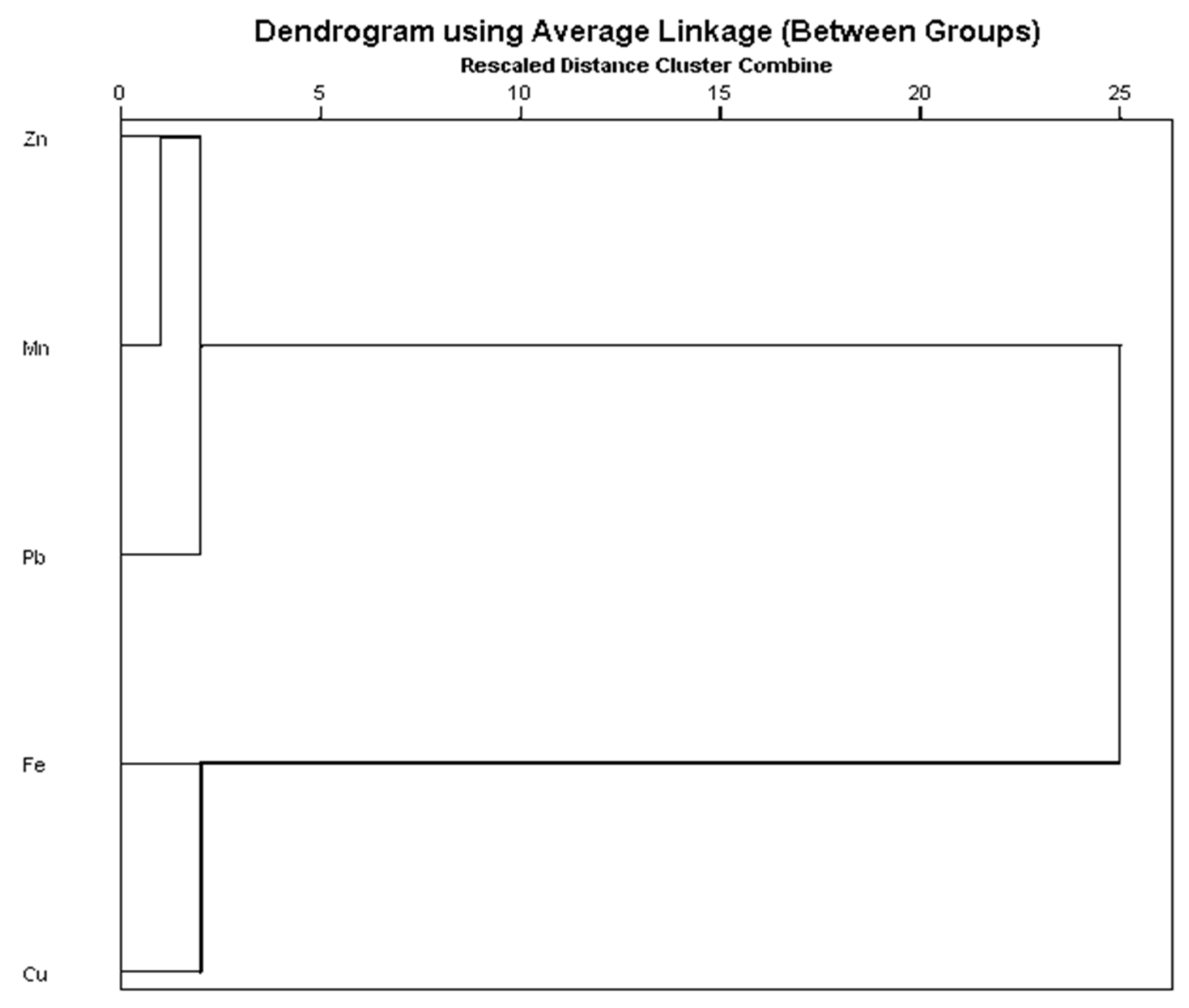

Figure 1. Dendrogram showing the inter-element clustering of the analyzed heavy metals. 
The results of the T-test analysis which is a comparison between the studied dust and the control dust is shown in Table 6. It was carried out at $95 \%$ confidence interval. The result indicates that there are significant differences between the concentrations of the metals in the contaminated and control soil dusts.

Table 6. $T$-test for the studied dust.

\begin{tabular}{lll}
\hline Elements $(\boldsymbol{\mu g} / \mathbf{g})$ & t-calculated & Remark \\
\hline $\mathrm{Fe}$ & 8.30 & $\mathrm{SD}$ \\
$\mathrm{Zn}$ & 41.48 & $\mathrm{SD}$ \\
$\mathrm{Mn}$ & 5.02 & $\mathrm{SD}$ \\
$\mathrm{Pb}$ & 9.31 & $\mathrm{SD}$ \\
$\mathrm{Cu}$ & 6.64 & $\mathrm{SD}$ \\
\hline
\end{tabular}

$\mathrm{T}_{\text {critical }}=2.30 \mathrm{SD}=$ Significant Difference.

The chemical fractionation of the investigated heavy metals is shown in Table 7.

Table 7. Chemical fractionation of heavy metals in dust soil samples.

\begin{tabular}{|c|c|c|c|c|c|c|}
\hline Element/fraction & Water soluble & Exchangeable & Carbonate bound & Fe-Mn bound & Organic bound & Residual or Inert \\
\hline \multirow{2}{*}{$\mathrm{Fe}$} & $3.78 \pm 0.50$ & $6.68 \pm 1.10$ & $3.98 \pm 0.12$ & $2.86 \pm 0.50$ & $4.16 \pm 0.41$ & $3.72 \pm 0.30$ \\
\hline & 15.05 & 26.53 & 15.81 & 11.36 & 16.52 & 15.01 \\
\hline \multirow{2}{*}{$\mathrm{Zn}$} & $0.44 \pm 0.02$ & $0.22 \pm 0.01$ & $1.32 \pm 0.15$ & $1.39 \pm 0.12$ & $0.94 \pm 0.01$ & $3.50 \pm 0.07$ \\
\hline & 5.63 & 2.82 & 16.90 & 17.80 & 12.04 & 44.81 \\
\hline \multirow{2}{*}{$\mathrm{Mn}$} & $1.68 \pm 0.11$ & $2.02 \pm 0.11$ & $1.86 \pm 0.12$ & $1.36 \pm 0.30$ & $1.42 \pm 0.05$ & $2.76 \pm 0.01$ \\
\hline & 15.12 & 18.20 & 16.76 & 12.25 & 12.79 & 24.86 \\
\hline $\mathrm{Pb}$ & $0.48 \pm 0.05$ & $0.52 \pm 0.05$ & $0.76 \pm 0.01$ & $2.78 \pm 0.04$ & $0.28 \pm 0.06$ & $0.68 \pm 0.50$ \\
\hline \multirow[b]{2}{*}{$\mathrm{Cu}$} & $2.48 \pm 0.03$ & $2.18 \pm 0.10$ & $4.22 \pm 0.50$ & $3.40 \pm 1.00$ & $6.60 \pm 0.13$ & $3.04 \pm 1.00$ \\
\hline & 11.31 & 9.95 & 19.25 & 15.51 & 30.11 & 13.87 \\
\hline
\end{tabular}

The average fractionation pattern of $\mathrm{Mn}$ in street dust samples of this study shows this order: residual $>$ Fe-Mn bound $>$ organic $\sim$ carbonate $>$ exchangeable. The percentage of residual $(25 \%)$ fractions demonstrated a combination of some natural and some anthropogenic sources like fossil fuel combustion and vehicle oils. Fe-Mn oxide was the second dominant fraction of $\mathrm{Mn}$ and confirmed that Fe-Mn oxides were efficient scavengers for this metal [23]. A combination of anthropogenic and natural origins could be considered for $\mathrm{Mn}$ in the dust samples in which are an indication that the anthropogenic source could also be related to traffic.

The average chemical associations of $\mathrm{Fe}$ in the street dusts samples shows the following order: exchangeable $>$ organic bound $>$ carbonate $>$ water soluble $\sim$ residual $>$ Fe-Mn bound. Similar results were obtained in previous studies on street dusts [24, 25] as exchangeable fraction was the dominant fraction in some studies on $\mathrm{Fe}$ fractionation of street dust samples [26]. Fe has a greater proportion in exchangeable phase $(27 \%)$ in comparison to other metals and thus this metal is more mobile than other metals. The high percentage $(85 \%)$ of non-residual fractions demonstrated high mobility, availability and anthropogenic resources for this metal. Fe is mainly from pesticides, fertilizers, car exhausts and building materials (metalliferous mines and smelting industries). Different fractions of $\mathrm{Zn}$ shows the following order: Residual $>$ Fe-Mn oxide $>$ Carbonate $>$ Organic $>$ Water soluble $>$ Exchangeable. The Zn adsorption onto the residual has higher stability constants than onto $\mathrm{Fe}$ $\mathrm{Mn}$ oxides which were reported to be the main carriers of $\mathrm{Zn}$ [25]. The same results were obtained in previous studies on street dusts [23]. The second important fraction of this metal was Fe-Mn oxide, maybe because of solidity of $\mathrm{Zn}$ oxides $[27,23]$ or Fe-Mn oxide might act as scavengers for this metal [28]. Carbonate phase is also an important fraction, probably due to the effect of calcite on street dust samples [25]. $\mathrm{CaCO}_{3}$ may adsorb $\mathrm{Zn}$ and form $\mathrm{CaCO}_{3} \cdot \mathrm{ZnCO}_{3}$ as a salt [23]. Averagely the proportion of $\mathrm{Zn}$ in non-residual fractions is $55 \%$, represented mobility and anthropogenic resources for this metal such as erosion of alloys in vehicle components and car covers [29, 30]. The average fractionation pattern of $\mathrm{Cu}$ shows the following order: organic $>$ carbonate $>\mathrm{Fe}-\mathrm{Mn}$ oxide $>$ residual $>$ water soluble $>$ exchangeable and about $30 \%$ of $\mathrm{Cu}$ is associated with organic phase. Similar results were obtained by the studies [25, 23] in street dusts. [31] Also demonstrated strong correlation between $\mathrm{Cu}$ and organic matter in soil sample. Because of $\mathrm{Cu}$ incorporation in clay minerals, residual fraction was an important phase of fractionation pattern [32]. On average, $86 \%$ of $\mathrm{Cu}$ is associated with non-residual fraction indicating the high risk and mobility of this metal and anthropogenic origin such as erosion of vehicle covers for copper in Tehran dust. Chemical association of $\mathrm{Pb}$ in street dust samples is as follows: Fe-Mn oxide $>$ residual $>$ carbonate $>$ exchangeable water soluble $>$ organic bound. $51 \%$ of $\mathrm{Pb}$ was associated with $\mathrm{Fe}-\mathrm{Mn}$ oxide fraction. Similar results acquired in previous research on street dusts [25]. Fe$\mathrm{Mn}$ oxides are effective scavenger for $\mathrm{Pb}[9,28]$ and the dominant association of this metal with Fe-Mn bound may be a result of $\mathrm{Pb}$ adsorption onto colloids of Fe-Mn $[23,28]$. The metal in this fraction may be released if the soil dust is subjected to more reducing conditions $[6,33]$. The second important fraction of this metal was carbonate because of 
lead carbonate formations [34]. High percentage (88\%) contribution of $\mathrm{Pb}$ in non-residual fractions confirms the contribution of traffic on the contamination of study area and is an indicator of anthropogenic source for this metal in street dust. It is evident from the results of the speciation study that the metals in the soil dusts are bound to different fractions with different strength. The strength values can, therefore, give a clear indication of dust reactivity, which in turn assess the risk connected with the presence of metals. Dust soil released in the same fraction more than $50 \%$ of the total metal has to be considered highly dangerous and can easily enter the food chain [35]. The present study reveals that about $45 \%$ of $\mathrm{Fe}$ at almost all the sites is exchangeable and carbonate bound and therefore comes under the high-risk category and can easily enter the food chain. Because of the availability and relative toxicity at high concentrations of $\mathrm{Fe}$, it can pose serious problem to the ecosystem. Also, most of the $\mathrm{Cu}$ in the samples shows dominance in the organic bound fraction $(33 \%)$ thus posing high risk to the environment. Speciation patterns of $\mathrm{Pb}(55 \%$ in the $\mathrm{Fe}-\mathrm{Mn})$ show a very high risk.

\subsection{Potential Ecological Risk Assessment}

The potential ecological risk assessment (RI) is presented in Table 5. The calculated RI is a reflection of the general situation of pollution brought about by the presence of individual metals. Considering the individual ecological risk index/potential ecological risk factor (Er), the dust samples exhibited a low contamination risk by all the investigated metal, while the dust samples also showed very low RI for the analyzed metals.

\subsection{Mobility Factor (MF)}

The mobility of the metals in the dust samples may be assessed on the basis of absolute and relative contents of extracts weakly bound to dust components. The relative index of metal mobility was calculated as a mobility factor [10]. Result of MF of the heavy metals in the studied dust samples is presented in Table 8 respectively.

Table 8. Heavy metals mobility factor (\%) in studied dust samples.

\begin{tabular}{llllll}
\hline Metals & Fe & Zn & Mn & Pb & Cu \\
\hline A & 53.97 & 45.33 & 56.07 & 39.58 & 46.53 \\
B & 47.37 & 18.48 & 53.48 & 46.29 & 37.69 \\
C & 35.49 & 28.17 & 53.66 & 40.54 & 40.70 \\
D & 29.96 & 20.43 & 45.16 & 37.78 & 25.24 \\
E & 59.52 & 15.52 & 39.81 & 8.79 & 52.58 \\
Mean & 45.26 & 25.59 & 49.64 & 34.59 & 40.55 \\
\hline
\end{tabular}

The indices of mobility are comparatively high for Mn with a mean value of $49.64 \%, \mathrm{Fe} 45.26 \%, \mathrm{Cu} 40.55 \%, \mathrm{~Pb}$ $34.59 \%$ and $\mathrm{Zn}$ has the lowest factor of $25.59 \%$. High mobility factor values have been interpreted as symptoms of relatively high lability and biological availability of heavy metals in dust [36]. On the overall, the results of the present study suggested that the mobility and bioavailability of the heavy metals examined decreases in the following order: $\mathrm{Mn}>\mathrm{Fe}>\mathrm{Cu}>\mathrm{Pb}>\mathrm{Zn}$.

\section{Conclusion}

Road side soil dusts from Ife-Ibadan express way, Osun state, Nigeria were examined for $\mathrm{Cu}, \mathrm{Pb}, \mathrm{Zn}, \mathrm{Fe}$ and $\mathrm{Mn}$. The result generally showed that the concentrations of the metals increased with traffic volumes. The pattern of the total mean concentration in the roadside soil dust followed $\mathrm{Fe}>\mathrm{Cu}>$ $\mathrm{Mn}>\mathrm{Zn}>\mathrm{Pb}$. The metals distribution profile in the soil dust showed that the concentrations of the concentration of the analyzed metals were higher than the maximum allowable limits. Fractionation of the metals species in soil dusts showed higher percentages of the metals residing in the nonresidual fractions. This suggested potential bioavailability of $\mathrm{Cu}, \mathrm{Zn}, \mathrm{Pb}$ in the vicinity of the high way is an indication of anthropogenic sources. Automotive emissions are the most effected contaminant source for heavy metal pollution in soil dusts. Some metal concentrations in the soil dusts were more than earth crust and those of other cities around the world.

\section{Recommendations}

Based upon the findings of this study, care should be taken to maintain a low level of contamination by metals on road side dusts. While the studied highway dusts show a low ecological risk, further studies should be carried out to monitor the bioaccumulation of these metals in the highway dusts. As a result of possible changes in soil conditions such as change in $\mathrm{pH}$ and total dissolved solids, further bioavailability studies should also be carried out to monitor the fate of these metals in the environment.

\section{Author Contributions}

In this paper, Festus Mayowa Adebiyi conceived and designed the experiments, Odunayo Timothy Ore and Godswill Ehimengbale Akhigbe performed the experiments. Odunayo Timothy Ore analyzed the data while Abiodun Odunlami Adegunwa prepared the manuscript. All authors read and approved the final version of the manuscript.

\section{Conflict of Interest Statement}

The authors declare that there is no conflict of interest.

\section{Acknowledgements}

The research did not receive any specific funding.

\section{References}

[1] Fakayode, S. O. and Olu-Owolabi, B. I. 2003. Heavy metal contamination of roadside topsoil in Oshogbo, Nigeria, its relationship to traffic density and proximity to highways. Environmental Geology 44; 150-157. 
[2] Geneva 1995. Air quality-Particle Size Fraction Definitions for Health-related Sampling ISO Standard 7708 International Organization for Standardization (ISO).

[3] Al-Khashman, O. A. 2004. Heavy metal distribution in dust, street dust and soils from the work place in Karak Industrial Estate, Jordan. Journal of Atmospheric Environment. 38, 6803-6812.

[4] Willers, S., Gerhardsson, L. and Lundh, T. 2005. Environmental tobacco smoke (ETS) exposure in children with asthma-relation between lead and cadmium, and nicotine concentrations in urine. Respiratory Medicine. 99: 1521-1527.

[5] Inyang, H. I. and Bae, S. 2006. Impacts of dust on environmental systems and human health. Journal of Hazardous Materials. 132: 5-6.

[6] Yuan C., Shi J., He B., Liu J., Liang L. and Jiang G. 2004. Speciation of heavy metals in marine sediments from the east China Sea by ICP-MS with sequential extraction, Environment International. 30: 769-783. Ahumadu, I., Mendoza, J. and Aser, L. 1999. Sequential extraction of heavy metals in soils irrigated with waste water common soil. Soil science and Plant Analysis. 30; 1507-1519.

[7] Da silva F. S., Moura A. M., Queiroz H. A., Ardisson, D. J. 2018. Chemical and spectroscopic characterization of tourmalines from the Mata Azul pegmatitic field, Central Brazil. Journal of GeoSciences. 63 (2): 155-165. DOI: http://dx.doi.org/10.3190/jgeosci.258.

[8] Kabala, C. and Singh, B. R. 2001. Fractionation and mobility of copper, lead, and zinc in soil profiles in the vicinity of a copper smelter. Journal of Environmental Quality. 30: 485-492.

[9] Tessier, A., Campbell, P. G. C. and Bisson, M. 1979. Sequential extraction procedure for the speciation of particulate trace metals. Analytical Chemistry. 51, 844-851.

[10] Salbu, B., Krekling, T. and Oughton, D. H. 1998. Characterization of radioactive particles in the environment. Analyst, 123: 843-849.

[11] Buccolieri, A., Buccolieri, G. and Cardellicchio, N. 2006. Heavy Metals in Marine Sediments of Taranto Gulf (Ionian Sea, Southern Italy). Marine chemistry. 99: 227-235.

[12] Abrahim, G. M. S. and Parker, P. J. 2008. Assessment of heavy metal enrichment factors and the degree of contamination in marine sediments from Tamaki Estuary, Auckland, New Zealand, Environmental Monitoring and Assessment, Vol. 136, No. 1-3, 227-238

[13] Duodu, G. O., Goonetilleke, A., Ayoko, G. A., 2016. Comparison of pollution indices for the assessment of heavy metal in Brisbane River sediment. Environmental Pollution. 219, 1077-1091.

[14] Oyewole, F. G. and Adebiyi, F. M. 2017. Total and speciation analyses of heavy metals in the sand fraction of Nigerian oil sands for human and ecological risk assessment. Human and Ecological Risk Assessment: An International Journal. 23 (8): 2046-2068.

[15] Bai, J., Cui, B., Wang, Q., Ga, H. and Ding, Q. 2008. Assessment of heavy metal contamination of roadside soils in Southwest China Stoch. Environmental Research and Risk Assessment. DOI 10.1007/s00477-008-0219-5.

[16] Bhattacharya, T., Chakraborty, S., Fadadu, B. and
Bhattacharya, P. 2011. Heavy metal concentration in street and Leaf deposited dust in Anand City, India, Journal of Chemical Sciences. Vol. 1 (5), 61-66.

[17] WHO 2007. Joint FAO/WHO, Expert standard programme codex Alimentation Commission. Geneva, Switzerland.

[18] Poggio, I., Vrscaj, B., Schulm, R. Heperle, E. and AjamonMarsan, F. 2009. Metal pollution and human Bioavailability of topsoil in Grugliasco (Italy) Journal of Environmental Pollution. 2: 680-689 doi: 10.1016/S0048-9697(99)0026-1.

[19] Lu, X., Lee, S., Wong, S., Shi, W. and Thornton, I. 2009. Contamination Assessment of zinc, lead, manganese, copper and nickel in street dust of Baoji, NW China. Journal of hazardous materials 161, 1058-1062.

[20] Kuo, C., Wang, J., Chang, S. and Chen, M. 2009. Study of metal concentrations in the environment near diesel transport routes. Atmospheric Environment. 43: 3070-3076.

[21] Mmolawa, K. B., Likuku, A. S. and Gaboutloeloe, G. K. 2010. Reconnaissance of heavy metal distribution and enrichment around Botswana. Fifth International Conference Environmental Science \& Technology, Houston, Texas USA July 12-16.

[22] Adebiyi, F. M., Asubiojo, I. O. and Ajayi, T. R. 2008. Elemental characterization of Nigerian oil sands by TXRF spectrometry. Petroleum Science and Technology. 25 (1), 29-39.

[23] Banerjee, A. D. K. 2003. Heavy metal levels and solid phase speciation in street dusts of Delhi, India. Environmental Pollution. 23, 95-105.

[24] Fergusson, J. E. and Kim, N. D. 1991. Trace elements in street and house dusts: sources and speciation. Science of the Total Environment. 100, 125-150.

[25] Li, X., Poon, C. S. and Liu, P. S. 2001. Heavy metal contamination of urban soils and street dusts in Hong Kong. Applied Geochemistry. 16, 1361-1368.

[26] Tokalioglu, S. and Kartal, S. 2006. Multivariate analysis of the data and speciation of heavy metals in street dust samples from the Organized Industrial District in Kayseri (Turkey). Atmospheric Environment. 40, 2797-2805.

[27] Fergusson, J. E. and Ryan, D. E. 1984. The elemental composition of street dust from large and small urban areas related to city type, source and particle size. Science of the Total Environment. 34, 101-116.

[28] Rath, P., Panda, U. C., Bhatta, D. and Sahu, K. C. 2009. Use of sequential leaching, mineralogy, morphology and multivariate statistical technique for quantifying metal pollution in highly polluted aquatic sediments-a case study: Brahmani and Nandira Rivers, India. Journal of Hazardous Materials. 163, 632-644.

[29] Jiries, A. 2003. Vehicular Contamination of Dust in Amman, Jordan. Environmentalist, 23, 205-210.

[30] Wei, B., Jiang, F., Li, X., Mu, S. 2010. Heavy metal induced ecological risk in the city of Urumqi, NW China. Environmental Monitoring Assessment. 160, 33-45.

[31] Adamo, P., Dudka, S., Wilson, M. J. and McHardy, W. J. 1996. Chemical and mineralogical forms of $\mathrm{Cu}$ and $\mathrm{Ni}$ in contaminated soils from the Sudbury mining and smelting region, Canada. Journal of Environmental Pollution. 91, 11-19. 
[32] Pickering, W. F. 1986. Metal ion speciation - soils and sediments (a review). Ore Geology Reviews, 1, 83-146.

[33] Singh, K. P., Mohan, D., Singh, V. K. and Malik, A. 2005. Studies on distribution and fractionation of heavy metals in Gomti river sediements-a tributary of the Ganges, India Journal of Hydrology. 312: 14-27.

[34] McAlister, J. J., Smith, B. J. and Torok, A. 2006. Element partitioning and potential mobility within surface dusts on buildings in a polluted urban environment, Budapest. Atmospheric Environment. 40, 6780-6790.
[35] Jain, C. K. 2004. Metal fractionation study on bed sediments of River Yamuna, India, Water Resources, 38: 569-578.

[36] Ahumada, I., J. Mendoza, E. Navarrete and L. Ascar, 1999. Sequential extraction of heavy metals in soils irrigated with wastewater. Communications in Soil Science and Plant Analysis, 30: 1507-1519. 